Provided for non-commercial research and education use. Not for reproduction, distribution or commercial use.

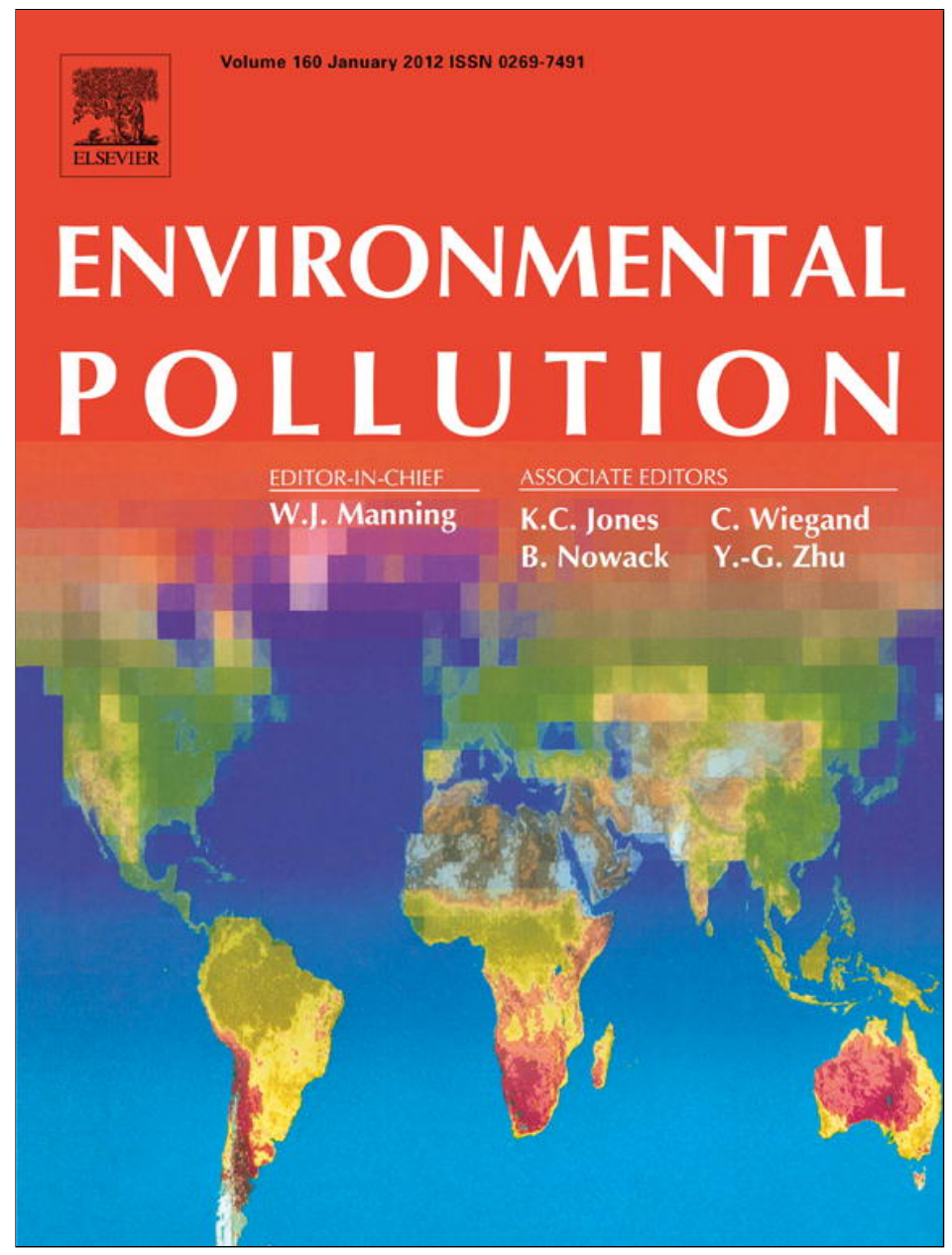

This article appeared in a journal published by Elsevier. The attached copy is furnished to the author for internal non-commercial research and education use, including for instruction at the authors institution and sharing with colleagues.

Other uses, including reproduction and distribution, or selling or licensing copies, or posting to personal, institutional or third party websites are prohibited.

In most cases authors are permitted to post their version of the article (e.g. in Word or Tex form) to their personal website or institutional repository. Authors requiring further information regarding Elsevier's archiving and manuscript policies are encouraged to visit:

http://www.elsevier.com/authorsrights 


\title{
Temporal variations of perfluoroalkyl substances and polybrominated diphenyl ethers in alpine snow
}

\author{
Torben Kirchgeorg a,b,c,*, Annekatrin Dreyer ${ }^{\text {a,d }}$, Jacopo Gabrieli ${ }^{\text {b,e }}$, Natalie Kehrwald ${ }^{\mathrm{b}}$, \\ Michael Sigl ${ }^{\mathrm{f}}$, Margit Schwikowski ${ }^{\mathrm{g}, \mathrm{h}, \mathrm{i}}$, Claude Boutron ${ }^{\mathrm{j}}$, Andrea Gambaro ${ }^{\mathrm{b}, \mathrm{e}}$, \\ Carlo Barbante $^{\mathrm{b}, \mathrm{e}}$, Ralf Ebinghaus ${ }^{\mathrm{a}}$ \\ ${ }^{a}$ Department for Environmental Chemistry, Institute of Coastal Research, Helmholtz-Zentrum Geesthacht, Max-Planck-Straße 1, 21502 Geesthacht, Germany \\ ${ }^{\mathrm{b}}$ Department of Environmental Sciences, Informatics and Statistics, University Ca' Foscari of Venice, Dorsoduro 2137, 30123 Venice, Italy \\ ${ }^{\mathrm{c}}$ Institute of Sustainable and Environmental Chemistry, Leuphana University of Lüneburg, Scharnhorststraße 1, 21335 Lüneburg, Germany \\ ${ }^{\mathrm{d}}$ Air Monitoring, Eurofins GfA GmbH, Stenzelring 14b, 21107 Hamburg, Germany \\ e Institute for the Dynamics of Environmental Processes, National Council of Research (IDPA-CNR), Dorsoduro 2137, 30123 Venice, Italy \\ ${ }^{\mathrm{f}}$ Desert Research Institute, 2215 Raggio Parkway, Reno, NV 89512, United States \\ ${ }^{\mathrm{g}}$ Laboratory of Radiochemistry and Environmental Chemistry, Paul Scherrer Institute, 5232 Villigen, Switzerland \\ ${ }^{\mathrm{h}}$ University of Bern, Department of Chemistry and Biochemistry, Freiestraße 3, 3012 Bern, Switzerland \\ i Oeschger Centre for Climate Change Research, University of Bern, Zähringerstrasse 2, 3012 Bern, Switzerland \\ ${ }^{\mathrm{j}}$ Laboratory of Glaciology and Geophysics of the Environment, University Joseph Fourier/CNRS, 54 rue Molière, 38402 Saint-Martin d'Hères, France
}

\section{A R T I C L E I N F O}

Article history:

Received 11 August 2012

Received in revised form

16 March 2013

Accepted 19 March 2013

\section{Keywords:}

PFAS

PBDE

European Alps

Deposition

Temporal trend

\begin{abstract}
A B S T R A C T
The occurrence and temporal variation of 18 perfluoroalkyl substances (PFASs) and 8 polybrominated diphenyl ethers (PBDEs) in the European Alps was investigated in a $10 \mathrm{~m}$ shallow firn core from Colle Gnifetti in the Monte Rosa Massif (4455 m above sea level). The firn core encompasses the years 1997-2007. Firn core sections were analyzed by liquid chromatography-tandem mass spectrometry (PFASs) and gas chromatography-mass spectrometry (PBDEs). We detected 12 PFASs and 8 PBDEs in the firn samples. Perfluorobutanoic acid (PFBA; $0.3-1.8 \mathrm{ng} \mathrm{L}^{-1}$ ) and perfluorooctanoic acid (PFOA; $0.2-0.6 \mathrm{ng} \mathrm{L}^{-1}$ ) were the major PFASs while BDE $99\left(<\mathrm{MQL}-4.5 \mathrm{ng} \mathrm{L}^{-1}\right)$ and BDE 47 (n.d. $\left.-2.6 \mathrm{ng} \mathrm{L}^{-1}\right)$ were the major PBDEs. This study demonstrates the occurrence of PFASs and PBDEs in the European Alps and provides the first evidence that PFASs compositions may be changing to PFBA-dominated compositions.
\end{abstract}

(c) 2013 Elsevier Ltd. All rights reserved.

\section{Introduction}

Industry has produced perfluoroalkyl substances (PFASs) and polybrominated diphenyl ethers (PBDEs) since the middle of the last century, but we are just beginning to understand their impacts on biotic and abiotic systems. An increasing number of scientific studies highlight the distribution, persistence, bioaccumulation potential and toxic properties of PFASs and PBDEs (Ahrens, 2011; Butt et al., 2010; Birnbaum and Staskal, 2003; De Wit, 2002; Dreyer et al., 2009a; Hites, 2004; Lau et al., 2007; Sturm and Ahrens, 2010). As a result of international environmental concerns culminating in the 2009 addition to the Stockholm Convention (Stockholm Convention 2009a,b), industry introduced voluntary phase-outs of these substances and governments launched restrictions for

\footnotetext{
* Corresponding author.

E-mail address: kirchgeorg@unive.it (T. Kirchgeorg).
}

the use and production of several PFASs (>C8) and PBDEs (3M, 2010; European Union, 2003, 2006).

Modeling studies predicted the long-range atmospheric transport of PBDEs to pristine ecosystems such as the Arctic (Breivik et al., 2006; Schenker et al., 2008b; Wania and Dugani, 2003). Observational studies confirm the model predictions and demonstrate that PBDEs can be atmospherically transported over long distances and to high mountain regions in the gaseous or particulate phase (Möller et al., 2011; Wang et al., 2009). The presence and phase of PBDEs in remote areas depends in part on environmental conditions. Temperature changes influence the partitioning of lessbrominated PBDEs between gaseous and particulate phases (Harner and Shoeib, 2002). Photolysis causes the debromination of BDE 209 (Schenker et al., 2008b) and this reaction is an additional source of less-brominated PBDEs. In contrast, the completelybrominated BDE 209 is present only in the particulate phase (Gouin et al., 2006). 
The atmospheric long-range transport of PFASs to remote regions is slightly more complicated than for PBDEs (Dreyer et al., 2009a; Loewen et al., 2008). Neutral volatile PFASs such as fluorotelomer alcohols (FTOHs) and perfluoroalkane sulfonamide substances are transported mainly in the gaseous phase and may degrade to less volatile perfluoroalkyl acids (PFAAs) including perfluoroalkyl carboxylic acids (PFCAs) and perfluoroalkane sulfonic acids (PFSAs) (Schenker et al. 2008a, Young and Mabury, 2010). These PFAAs can also be directly emitted to the atmosphere by manufacturing processes (Barton et al., 2006) where they are bound onto particles or dissolved in cloud, rain, or fog droplets (Arp and Goss, 2009).

Alpine ice and firn cores or snow pit samples provide records of classical organic pollutants such as pesticides, polycyclic aromatic hydrocarbons (PAHs) or polychlorinated biphenyl (PCBs) to estimate temporal or seasonal trends and/or reconstruct historical deposition (Gabrieli et al., 2010; Villa et al., 2006). To the best of our knowledge, researchers have only studied ice or snow cores as a natural archive for airborne PFASs or PBDEs in the Arctic (Hermanson et al., 2010; Meyer et al., 2012; Young et al., 2007). Other types of natural archives or sampling techniques that record temporal trends of PBDEs include long-term passive sampling (Schuster et al., 2010), vegetation and soil samples (Hassanin et al., 2005; Schuster et al., 2011), and lake sediment cores (Bogdal et al., 2008; Kohler et al., 2008). Peat bogs, human serum, sediment cores and associated biota record PFASs back to the 1950s (Ahrens et al., 2009; Dreyer et al., 2012; Sturm and Ahrens, 2010). However, sediment cores are influenced by their catchment areas and it is difficult to separate atmospheric and aquatic signals (Shotyk et al., 2004). Biota and human serum are influenced by different sources (diet, water, air) that complicate determining decadal trends. Short chain PFASs $(<\mathrm{C} 8)$ are only negligibly bio-accumulative and therefore do not provide temporal trends in biological materials.

Accumulating persistent organic pollutants in the European Alps is a concern as glaciers preserve pollutants and can later release these pollutants into regional water resources (Bogdal et al., 2009). The Alps are the largest natural air barrier in central Europe and a potential trap for European anthropogenic atmospheric pollution (Eichler et al., 2004). Here, we use a $10 \mathrm{~m}$ firn core (Colle Gnifetti, Monte Rosa massif, Swiss/Italian Border, 4455 m above sea level; a.s.l.) to provide the first analysis of PFASs and PBDEs in the Alps. The objective of the study is to provide insight into airborne PFAS and PBDE concentrations between 1997 and 2007, thereby encompassing the time period of voluntary phase-outs and bans of the investigated chemicals. We examine if the changes in production and use of these chemicals resulted in decreased environmental concentrations.

\section{Material and methods}

\subsection{Sampling and dating}

In August 2008, a $10 \mathrm{~m}$ long $6 \mathrm{~cm}$ diameter firn core (CG-08) was collected on Colle Gnifetti $\left(45^{\circ} 55^{\prime} 51^{\prime \prime} \mathrm{N}, 07^{\circ} 52^{\prime} 34^{\prime \prime} \mathrm{E}, 4455 \mathrm{~m}\right.$ a.s.l., Monte Rosa massif, near the Swiss/Italian border). Firn is compacted snow with a density of $400-830 \mathrm{~kg} \mathrm{~m}^{-3}$ that has not yet reached the $>830 \mathrm{~kg} \mathrm{~m}^{-3}$ density of glacial ice (Cuffey and Paterson, 2010). The mean density of the firn core is $516 \mathrm{~kg} \mathrm{~m}^{-3}$ and the accumulation at this site is $0.44 \mathrm{~m}$ w.eq. $\mathrm{yr}^{-1}$ (water equivalent) with a range of $0.3-0.6 \mathrm{~m}$ w.eq. $\mathrm{yr}^{-1}$ during the studied period. This accumulation is within the reported accumulation range at this location between 0.1 and $1 \mathrm{~m}$ w.eq. $\mathrm{yr}^{-1}$ (Suter and Hoelzle, 2002). Colle Gnifetti has a relatively low net accumulation compared to other Alpine summits. Accumulation primarily occurs during spring, while winter snow is mostly eroded by strong local winds. Melting is negligible as indicated by the visual observation of few melt features rarely exceeding $1 \mathrm{~cm}$ thickness. The CG-08 core was dated by annual layer counting using the seasonally-varying $\delta^{18} \mathrm{O}$ ratios and $\mathrm{NH}_{4}^{+}$concentrations (Fig. 2) and by matching previously-detected Saharan dust horizons (A.D. $2000,1999,1996$ ) with the CG-03 core (Jenk et al., 2009). All details dating and anion analyses details are included in Sigl (2009).

\subsection{Sample preparation}

Firn core sections with lengths from 33 to $74 \mathrm{~cm}$ were combined to obtain continuous samples with annual resolution. We analyzed a total of 13 samples including incomplete annual sections at the beginning and the end of the core (1996, 2008). Samples were melted at room temperature in a Class 1000 clean room. Solid phase extraction was performed with $1.5 \mathrm{~g}$ self-packed PAD-II glass columns connected to the top of OASIS WAX cartridges ( $6 \mathrm{cc}, 150 \mathrm{mg}$, Waters, United States). Prior to extraction, melted water was spiked with $50 \mu \mathrm{L}$ of a standard solution containing mass-labeled PFASs $\left({ }^{18} \mathrm{O}_{2}\right.$-PFHxS, ${ }^{13} \mathrm{C}_{4}$-PFOS, ${ }^{13} \mathrm{C}_{4}$-PFBA, ${ }^{13} \mathrm{C}_{4}$-PFHxA, ${ }^{13} \mathrm{C}_{4}$-PFOA, ${ }^{13} \mathrm{C}_{4}$ PFNA, ${ }^{13} \mathrm{C}_{4}$-PFDA, ${ }^{13} \mathrm{C}_{4}$-PFUnDa, ${ }^{13} \mathrm{C}_{4}$-PFDoDa, ${ }^{13} \mathrm{C}_{8}$-FOSA; concentration of each mass-labeled standard $\left.=20 \mathrm{pg} \mu \mathrm{L}^{-1}\right)$, and $50 \mu \mathrm{L}$ of a PBDE standard solution $\left({ }^{13} \mathrm{C}_{12}\right.$ BDE 77, ${ }^{13} \mathrm{C}_{12}$-BDE 138, ${ }^{13} \mathrm{C}_{12}$-BDE 209; concentration of each mass-labeled

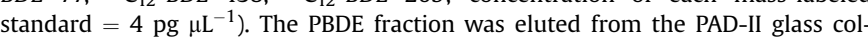
umns with hexane and hexane:dichloromethane $(1: 1, \mathrm{v}: \mathrm{v})$. The PFAS fraction was eluted with methanol and $0.1 \%$ ammonium hydroxide in methanol from the PAD-II glass columns and the OASIS Wax cartridges. The supporting information (SI) included full extraction method details and information about suppliers, purities and acronyms of chemicals, mass-labeled and native standards (Table SI 1).

\subsection{Instrumental analyses}

We determined 18 perfluoroalkyl substances (PFBS, PFHxS, PFHpS, PFOS, PFDS, PFBA, PFPA, PFHxA, PFHpA, PFOA, PFNA, PFDA, PFUnDA, PFDoDA, PFTrDA, PFTeDA, PFHxDA, PFOcDA; full names in the SI) by high performance liquid chromatography (HP 1100, Agilent Technologies, Waldbronn, Germany) electrospray ionization (negative mode) tandem mass spectrometry (HPLC-ESI(-)-MS/MS; API 3000, AB Sciex, Darmstadt, Germany) using a Synergi Hydro RP 80A column (Phenomenex, USA; $150 \times 2 \mathrm{~mm}, 4$ micron). All details and specifications concerning the HPLCMS/MS measurements are described by Kirchgeorg et al. (2010).

We analyzed 8 PBDEs (BDE 28, BDE 47, BDE 99, BDE 100, BDE 153, BDE 154, BDE 183, BDE 209) by gas chromatography-mass spectrometry (GC-MS, 6890N - 5975 MSD System, Agilent Technologies) using negative chemical ionization ( $\mathrm{NCI}$ ). Analytes were separated on a HP-5MS column (Agilent Technologies, $30 \mathrm{~m}$ length $250 \mu \mathrm{m}$ diameter, $25 \mu \mathrm{m}$ film thickness). Specifications and programmed temperatures were adapted from Weinberg et al. (2011a). Due to the low expected concentrations $\left(<1 \mathrm{ng} \mathrm{L}^{-1}\right)$, PBDEs were detected on the mass to charge ratio $79 / 81$ which is more sensitive compared to the more specific molecular masses. When concentrations were sufficiently high, molecular-specific mass to charge ratios were used (Weinberg et al., 2011a). Quantification was based on peak areas. Analyte concentrations were calculated with the internal standard method based on response factors using mass-labeled internal standards. Analyte concentrations were calculated with nine point calibrations. Method detection and quantification limits (MDL, MQL) for PFASs calculated on the basis of signal to noise ratios ( $\mathrm{S} / \mathrm{N}$ of $3=\mathrm{MDL}, \mathrm{S} / \mathrm{N}$ of $10=\mathrm{MQL}$ ) in firn core samples ranged between 0.01 (PFPA) $0.08 \mathrm{ng} \mathrm{L}^{-1}$ (PFUnDA) and 0.03 (PFPA) $-0.25 \mathrm{ng} \mathrm{L}^{-1}$ (PFBA), respectively. PBDE MDLs and MQLs were between 0.01 (BDE 47) - $0.33 \mathrm{ng} \mathrm{L}^{-1}$ (BDE 209) and 0.04 (BDE 47) $1.1 \mathrm{ng} \mathrm{L}^{-1}$ (BDE 209), respectively. Detailed information about MDLs and MQLs is provided in the supporting information (Table SI 4).

\subsection{Quality assurance/quality control}

Sample preparation and extraction were conducted in clean labs. PFAScontaining materials were avoided during sampling, preparation, laboratory work and instrumental analysis. Glassware, non-glass items, tables, guides and the blade for cutting and handling the core were carefully cleaned with methanol and acetone before each use. Mass-labeled internal standards were used to correct losses occurring during laboratory work and instrumental analyses. Recovery rates (standard deviation in brackets) were determined in a preliminary extraction experiment $(n=5)$ using the extraction procedure described above and were between $79 \%( \pm 8$ $\mathrm{PFHpA})$ and $114 \%( \pm 3$ PFBA $)$ and $85 \%( \pm 10, \mathrm{BDE} 28)$ and $113 \%( \pm 7, \mathrm{BDE} 153)$. A set of 4 firn core samples and 1 laboratory blank of $1 \mathrm{~L}$ Millipore water were extracted simultaneously. Detected PFAS and PBDE concentrations were below the quantification limit in the blanks (Table SI 5). The combined uncertainty according to the Eurachem/CITAC guidelines (Ellision and Williams, 2000) calculated from mean concentration of the ice core samples ranged from 4\% (PFUnDA) to $200 \%$ (PFPA) and from $10 \%$ (BDE 47 ) to $42 \%$ (BDE 209) for PFASs and PBDEs.

\subsection{Statistical analyses and calculation of annual deposition}

Statistical analyses were performed with Winstat (Version 2007, R. Fitch Software, Bad Krozingen, Germany) and Origin 8G (OriginLaB Corporation, Northampton, USA). Normal distribution of analyte concentrations was determined using the Kolmogorov-Smirnov-Test. Compounds detected in less than $50 \%$ of the samples were excluded from the statistical analyses. Spearman rank correlations were applied to investigate relationships between analytes and firn core parameters. Regression analyses were used to evaluate any trends. 5 year moving averages of pollutant deposition were calculated on the basis of the measured concentrations in 
the melted ice core samples and the accumulated snow (concentration $\times$ snow depth $\times$ density).

\section{Results and discussion}

\subsection{Concentrations and variations}

\subsubsection{Perfluoroalkyl substances}

PFAS concentrations in all firn core sections between 1996 and 2008 were in the low $\mathrm{ng} \mathrm{L}^{-1}$ range. Of the determined PFASs, 12 of 18 examined PFASs (PFOS, PFBA, PFPA, PFHxA, PFHpA, PFOA, PFNA, PFDA, PFUnDA, PFDoDA, PFTrDA, PFTeDA) were above the MDL (Table SI 6). The majority of the PFCAs were the following compounds, where their proportion of the total PFAS concentrations are included in parentheses: PFBA $0.34-1.83 \mathrm{ng} \mathrm{L}^{-1}$ (26-63\%); PFOA $0.20-0.63 \mathrm{ng} \mathrm{L}^{-1}(11-33 \%)$; PFNA $<\mathrm{MQL}-0.31 \mathrm{ng} \mathrm{L}^{-1}(0-15 \%)$; PFDA $<$ MQL $-0.31 \mathrm{ng} \mathrm{L}^{-1}(0-15 \%)$. PFOS was detected but concentration levels were below the MQL. Total PFAS concentrations by depth and the relative proportions of individual PFASs are illustrated in Fig. 1.

PFCA concentrations in the Colle Gnifetti firn core are up to one order of magnitude higher than concentrations reported in ice core samples across the Canadian Arctic (Young et al., 2007). PFAS concentrations in precipitation from rural or urban regions in Europe and North America were up to two orders of magnitude higher than those at Colle Gniffetti (Dreyer et al., 2010; Kwok et al., 2010; Scott et al., 2006). As expected, firn core concentrations at high altitudes were lower than reported concentrations close to urban regions.

\subsubsection{Polybrominated diphenyl ethers}

All of the investigated eight PBDEs were observed in the $10 \mathrm{~m}$ firn core from Colle Gnifetti, where their concentrations and proportions of the total PBDE concentration vary with depth (Fig. 2, Table SI 7). BDE 47 (concentration: n.d.-2.61 ng L ${ }^{-1}$, proportions: 0-100\%), BDE 99 (<MQL-4.54 $\mathrm{ng} \mathrm{L}^{-1}, 0-100 \%$ ) and BDE 100 (n.d.$0.74 \mathrm{ng} \mathrm{L}^{-1}, 0-17 \%$ ) were detected most frequently and with the highest concentrations of the group. The higher-brominated BDE 153 (n.d. $-0.46 \mathrm{ng} \mathrm{L}^{-1} ; 0-6 \%$ ), BDE 154 (n.d. $-0.32 \mathrm{ng} \mathrm{L}^{-1}, 0-4 \%$ ), and BDE 183 (n.d.-<MQL; 0\%) were only detected in a few samples. BDE 209 (n.d. $-2.85 \mathrm{ng} \mathrm{L}^{-1}, 0-97 \%$ ) was detected above the MQL in three samples, in four samples it was above the $\operatorname{MDL}\left(>0.33 \mathrm{ng} \mathrm{L}^{-1}\right)$ but below the MQL $\left(<1.1 \mathrm{ng} \mathrm{L}^{-1}\right)$.

The predominance of BDE 99 and BDE 47 is similar to other studies of European Alpine snowpack. BDE 47 tends to predominate in air samples while precipitation is partly characterized by higher BDE 99 concentrations (Arellano et al., 2011; Möller et al., 2011; Ter Schure and Larsson, 2002). The elevated firn core concentrations for 1997, 1998 and 2002 were up to two orders of magnitude higher than those reported in snowpack from the Tatra Mountains, Slovakia (1683-2634 m a.s.l.; Arellano et al., 2011), rainwater at Lake Maggiore, Italy (Mariani et al., 2008) or rainwater in Sweden (Ter Schure and Larsson, 2002). After excluding these few high peaks, the concentrations of the remaining years are comparable to reported European PBDE concentrations. Several previous studies observed high BDE 209 concentrations in precipitation (Mariani et al., 2008; Offenthaler et al., 2009), but due to high MQL for BDE 209 in this study we do not have enough data for a comparison.

\subsection{Atmospheric deposition rates}

In order to obtain an approximation of the actual atmospheric deposition to the Alpine region, we calculated average contaminant deposition as described the method section. However, concentrations of persistent organic pollutants are influenced by several postdepositional effects such as volatilization and degradation of compounds, dissolution of substances in meltwater or wind scour of deposited snow (Daly and Wania, 2004; Wania, 1997). Colle Gnifetti air temperatures during the investigated period were almost always below $0{ }^{\circ} \mathrm{C}$ and the borehole temperatures ranged from $-12.5^{\circ} \mathrm{C}$ to $-13.5^{\circ} \mathrm{C}$, minimizing the risk of snow melt and meltwater percolation. The well-preserved chemical and isotopic profiles and the presence of few visible ice lenses in the core confirm the lack of melt. Conditions with mean annual temperatures below $0{ }^{\circ} \mathrm{C}$ reduce the degradation of persistent organic compounds and affect the revolatilization of PBDEs and PFASs. However, temperature affects revolatilization even at low temperatures and may influence BDE 47, BDE 99 and BDE 100 concentrations (Bossi et al., 2008). Colle Gnifetti is also susceptible to wind erosion, which may enhance the revolatilization of lighter PBDEs (Meyer et al., 2012). Wind erosion predominantly removes the winter snow leading to a low annual net accumulation rate preserving only $7-41 \%$ of the originally deposited snow on the mountain (Schwikowski et al., 2004). The pollution signal trapped in the net Colle Gnifetti accumulation represents non-winter deposition. The enhanced atmospheric mixing during the summer results in increased trace species deposition (Eichler et al., 2004), and we assume that this relationship applied to PFAS and PBDE deposition. Thus the derived deposition is assumed to reflect annual deposition. However, all of these aspects enhance the uncertainty of atmospheric deposition

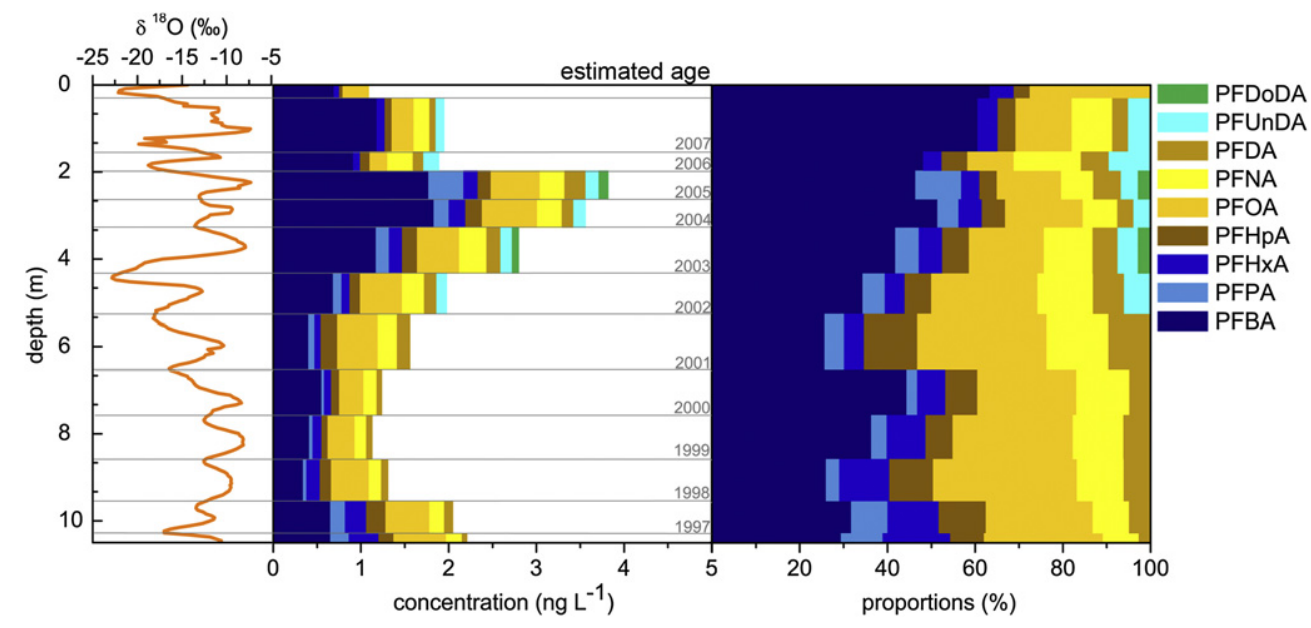

Fig. 1. Depth profiles of concentrations ( $\mathrm{ng} \mathrm{L}^{-1}$ ) and proportions (\%) of the most frequently detected PFASs. The orange line depicts the $\delta^{18} \mathrm{O}$ ratio, used as a proxy for dating. PFASs (PFOS, PFTrDA, PFTeDA) below the MQL are not included. 


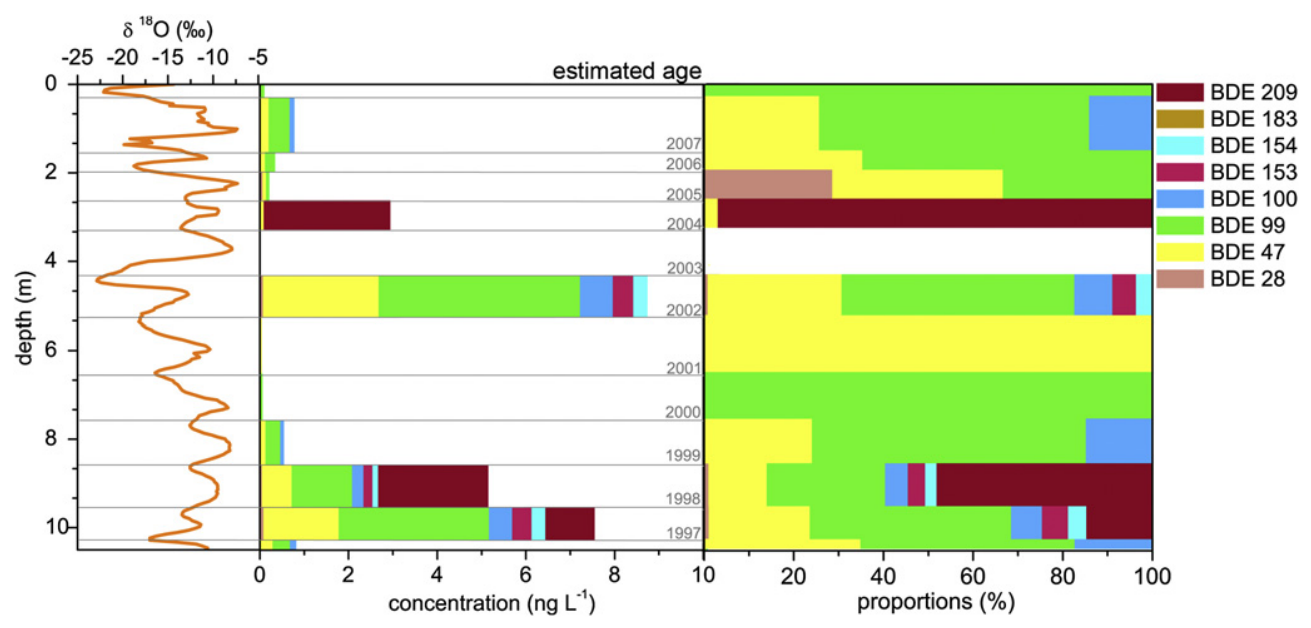

Fig. 2. Depth profiles of concentrations ( $\mathrm{ng} \mathrm{L}^{-1}$ ) and proportions (\%) of detected PBDEs. The orange line depicts the $\delta^{18} \mathrm{O}$ ratio, used as a proxy for dating.

estimates (Table SI 8). To overcome the varying accumulation rates we calculated 5-year averages that resulted in a total PFAS deposition of $756 \mathrm{ng} \mathrm{m}^{-2} \mathrm{yr}^{-1}(1997-2001)$ and $1091 \mathrm{ng} \mathrm{m}^{-2} \mathrm{yr}^{-1}(2003-$ 2007) with a total PBDE deposition of 1324 (1997-2001) and $325 \mathrm{ng} \mathrm{m}^{-2} \mathrm{yr}^{-1}$ (2003-2007) (SI Table 8).

Reported PFAS and PBDE deposition rates (Table 1) provide a limited comparison because precipitation data at the recording sites are influenced by effects other than those influencing the high alpine ice core locations. European ice core data for these compounds is very limited, thus this comparison helps provide a rough contamination level. Average PFAS deposition rates at Colle Gnifetti were up to 4 times higher than in the Canadian Arctic (Young et al., 2007). Deposition rates at Colle Gnifetti were in the same range as those reported from precipitation in remote regions in Canada (Northern Ontario and Novia Scotia) (Table 1). In Europe, Dreyer et al. (2010) determined significantly higher PFAS deposition in precipitation close to Hamburg (Germany) compared to the estimated deposition in the present study. Kwok et al. (2010) reported higher fluxes from residential, business and industrial areas in Japan and the US and Scott et al. (2006) also describe increased PFAS deposition from near-urban and rural places in the US.

In comparison to previous PBDE studies from the European Alps, deposition rates were determined in fresh fallen snow collected with a deposition sampler at three Alpine summits (Weissfluhjoch, Switzerland, $2663 \mathrm{~m}$ a.s.l., Zugspitze, Germany, $2650 \mathrm{~m}$. a.s.l. and Sonnblick, Austria, $3100 \mathrm{~m}$ a.s.l.) by Offenthaler et al. (2009). Excluding the summit Sonnblick where the authors suggested a local source contamination, the deposition of BDE 209 at two summits (Weissfluhjoch and Zugspitze) was up to 2 orders of magnitude higher than values at Colle Gnifetti. The lower altitude of these summits compared to Colle Gnifetti may be a reason for their higher concentrations. In contrast, the remaining lowerbrominated PBDEs were up to one order of magnitude higher at Colle Gnifetti. The possibility of different source regions and transport behavior as a reason for these differing concentrations is discussed in detail in the following sections.

\subsection{Sources of PFASs}

The measured PFAS composition compared to the composition of snow from skiing regions subjected to ski waxes (Freberg et al., 2010) suggests that direct contamination from human activities (skiing, sampling campaigns) is negligible for the sampling location. We therefore assume that PFAS contamination has completely resulted from atmospheric wet and dry deposition. In general, Colle
Gnifetti is influenced by the westerly wind systems (Eichler et al., 2004). During summer months the majority of precipitation arrives by convective activity. In summer the planetary boundary layer is located at higher altitudes and air masses from local sources may be able to reach this altitude ( $>4000 \mathrm{~m}$. a.s.l.) (Lugauer et al., 1998).

Primary emission sources of particle-bound and gaseous PFASs include manufacturing processes, waste-related facilities and waste water treatment plants. PFASs can be released and volatized as a result using products containing PFASs (e.g. lubricants) (Fiedler et al., 2010). Secondary emission sources to the atmosphere include sea spray generation and the degradation of volatile precursor substances (Webster and Ellis, 2010; Young and Mabury, 2010). PFASs originating from sea spray may be a source of PFASs (Reth et al., 2011), but we only observed low sea salt tracer concentrations in the firn core, indicating a low influence of marine air masses. In addition, PFAS concentrations did not correlate with sodium and chloride $(p>0.1)$, suggesting that marine sea spray formation may be negligible for Colle Gnifetti PFAS contamination.

Armitage et al. (2009) estimated PFOA:PFNA ratios for direct emissions from manufacturing processes of 7:1-15:1 for Europe/ Russia and Asia. In the present study PFOA:PFNA ratios were between 0.7:1 and 3.3:1 suggesting a influence of secondary sources such as the degradation of volatile precursor substances. The PFOA:PFNA ratio at Colle Gnifetti is close to the ratio of $1.5 \pm 0.8$ reported from the Canadian Arctic (Young et al., 2007) corroborating the hypothesis of an indirect contamination origin for these PFCAs. Previous studies assumed that the occurrence of longer chain PFASs ( $>$ C 10) is an indicator of atmospheric degradation of volatile precursors, as significant commercial sources are not known (Prevedouros et al., 2006). In addition none of these $>C 8$ PFCAs correlate with sulfate in the firn core, where sulfate was used for to identify the influence of local aerosol rich air masses. This suggests that the major source of $>$ C8 PFCAs might be the degradation of volatile precursors which can be transported over long distances and do not have to originate from local sources.

In contrast to longer-chain PFCAs ( $>$ C8), elevated PFBA concentrations at Colle Gnifetti cannot be explained by the atmospheric degradation of volatile precursors, as studies only report very low concentrations of 4:2 FTOH in central European ambient air (Dreyer et al., 2009b). Although PFBA can be atmospherically formed by several volatile precursors with a chain length $>\mathrm{C} 4$, the degradation of long-chain precursors (e.g. 8:2 FTOH) would primarily result in the formation of PFOA and PFNA. This lack of degradation suggests that PFBA originated from direct emissions. 
Table 1

Comparison of PFAS and PBDE deposition fluxes $\left(\mathrm{ng} \mathrm{m}^{-2} \mathrm{yr}^{-1}\right)$.

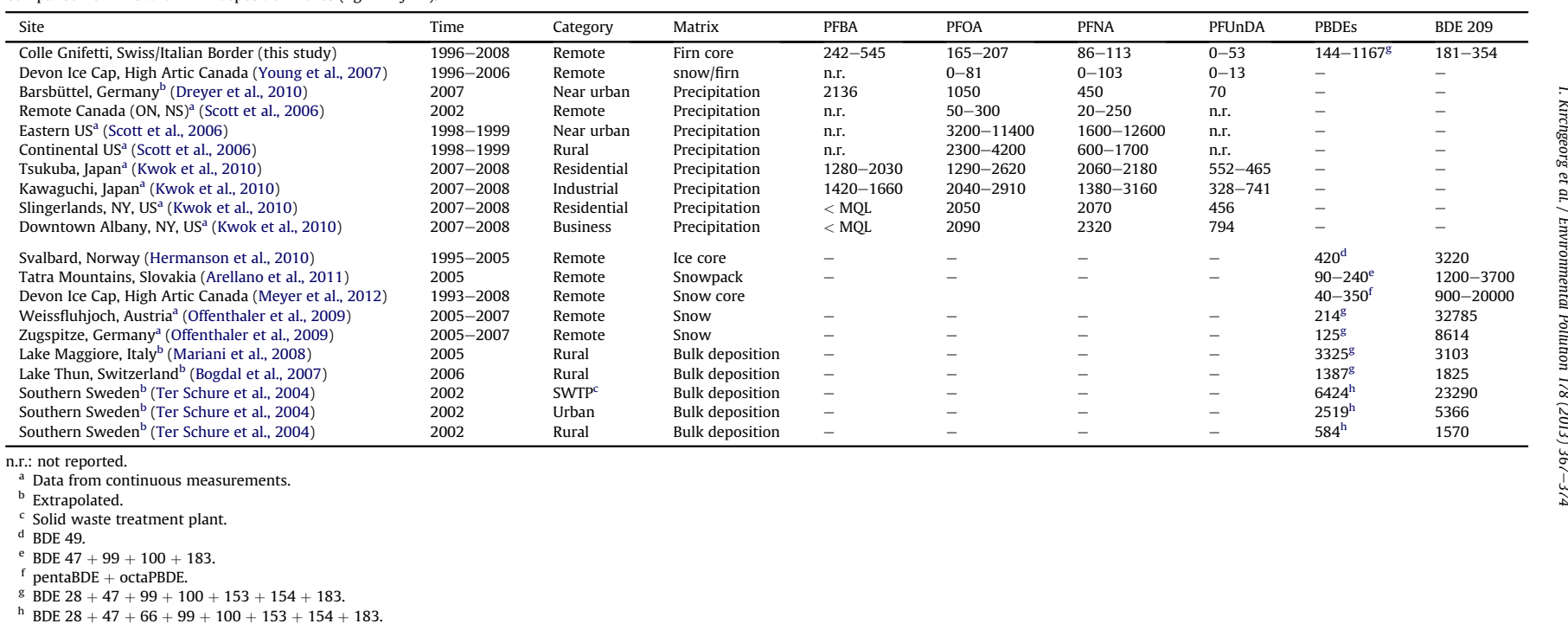


As PFBA vapor pressure is higher than that of PFOA or other longchain PFAAs, the atmospheric transport efficiency in the gasphase to higher altitudes may be enhanced (Kaiser et al., 2005; Steele et al., 2002). If PFBA only originates from direct local emissions, we would expect a correlation with sulfate or ammonia, a tracer for aerosol-rich air masses. However, PFBA does not correlate with sulfate or ammonia, suggesting that it is not only influenced by local sources.

The voluntary phase-out and replacement of PFOS may explain the low concentrations ( $<\mathrm{MQL}$ ) observed in Colle Gnifetti firn. Ahrens et al. (2010) suggested that in contrast to PFCAs, PFOS deposition in high altitude European Alpine lakes (1649-2448 m a.s.l.) is mainly related to the atmospheric degradation of low concentration volatile precursors and not from direct emissions of PFOS to the atmosphere. Low PFOS concentrations on Colle Gnifetti may also result from the different atmospheric transport behavior of directly-emitted PFSAs compared to PFCAs, due to their different gas-particle partitioning and particle size-distribution. PFSAs were reported to be almost $100 \%$ absorbed to particles whereas PFCAs showed different partitioning behavior regarding their chainlength (Vierke et al., 2011). Furthermore, PFSAs tend to absorb to larger particles than PFCAs (Dreyer et al., 2011). Wet or dry deposition may effectively remove particles before they reach altitudes above $4000 \mathrm{~m}$.

\subsection{Sources of PBDEs}

The analyzed PBDEs may have originated from primary sources such as emissions from manufacturing processes, waste-related facilities, or from the release of PBDE-containing products to the atmosphere (Watanabe, 2003; Weinberg et al., 2011a,b). In 2003, Directive 2003/11/EC (European Union, 2003) banned using or producing pentaBDE and octaBDE mixtures in Europe. The ban included BDE 209 in 2008, which is outside the investigated period. The predominance of BDE 47 and BDE 99 is typical for technical pentaBDE mixtures. However, these compounds can also originate from secondary sources such as the debromination of BDE 209 (Schenker et al., 2008b) and/or condensation and re-volatilization processes at lower altitudes. BDE 209 is strongly influenced by direct sources, while lower brominated BDEs are influenced by a combination of primary and secondary sources (Gouin et al., 2006).

We used sulfate and ammonium as tracers for aerosol-rich air masses influenced by anthropogenic activates to obtain a rough estimate of the potential origin of PBDEs. We did not observe any correlations between BDE 99 and BDE 47 with sulfate and ammonium $(p>0.1)$. This lack of correlation suggests that PBDEs do not primarily originate from aerosol-rich air masses from source regions. Due to the limited dataset, we did not perform correlation analyses for the remaining PBDEs. Belis et al. (2009) reported PBDE concentrations in humus, soil and spruce needles from different locations and altitudes in the European Alps. The highest PBDE loads were observed in Italy. During the summer, re-volatilization from humus and soil in lower altitudes and cold condensation in higher altitudes may be other PBDEs sources in high alpine regions and may explain the observed elevated concentrations of BDE 47 and BDE 99 in the present study (Gouin et al., 2006; Wania and Westgate, 2008). Increasing concentrations with altitude were recently observed for all PBDEs except for BDE 209 in the Tatra Mountains, Slovakia (1683-2634 m a.s.l.) (Arellano et al., 2011).

\subsection{Temporal variations}

Despite recent efforts to reduce PFASs in the environment, we only observe a slight decrease in PFOA concentrations in the firn. We detected PFUnDA in samples after 2002. PFBA, one substitute

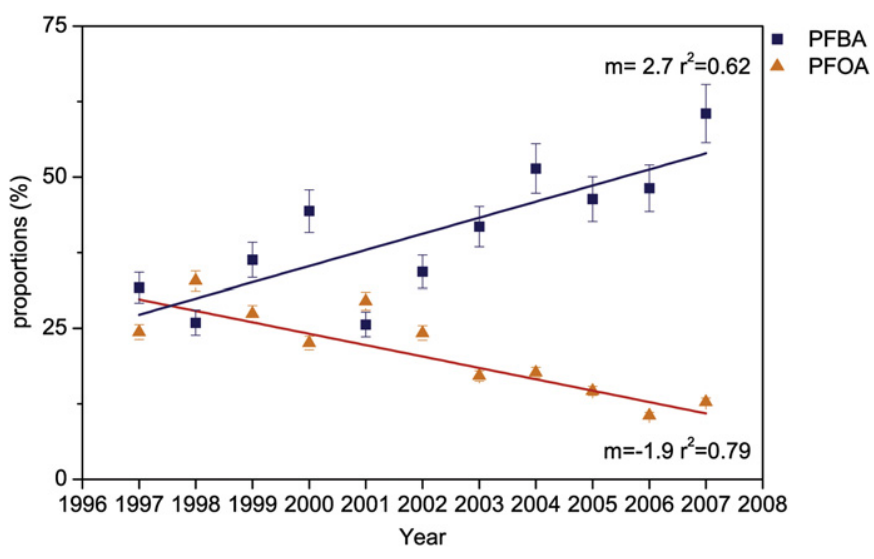

Fig. 3. Annual proportion (\%) changes of PFBA and PFOA from 1997 to 2007. Trend line: linear regression. Error bars: combined method uncertainty.

for longer chain PFCAs, increased during the same time period. PFCA concentrations in the snow are strongly influenced by changing weather conditions and the snow accumulation. However, we observed a significant change in PFAS proportions (Figure SI 1) over the studied time period. PFBA proportions (Fig. 3) increased significantly $(p<0.01)$ in the most recent years and are responsible for the overall increase in the total estimate of the 5year depositional averages. This corroborates recent atmospheric measurements where PFBA was the most abundant PFCA (Ahrens et al., 2012). PFHpA ( $p<0.01)$, and PFOA proportions decreased $(p<0.001)$ during this period probably as result of recent replacements of C8-PFASs by their short-chain analogs (Renner, 2006). Long-term atmospheric deposition data is limited, and recent European temporal trend studies for $>$ C8 PFCAs from biota samples reported different trends for the period after 2000 (Ahrens et al., 2011; Kratzer et al., 2011). Short chain PFASs are less bioaccumulative, thus the shift to shorter chain PFASs cannot be observed in temporal trend studies conducted in biota. Therefore data regarding temporal trends of $<$ C8 PFCAs are limited.

The PBDE concentrations and proportions did not indicate any significant trend due to both elevated concentrations in three samples and missing data from concentrations below the quantification limit (Table SI 4). Due to this data variability, we cannot confirm a decline in PBDE concentrations after their regulation. Recent studies of temporal trends of PBDEs in different matrixes also show no clear trends (Bogdal et al., 2008; Hermanson et al., 2010; Kohler et al., 2008; Meyer et al., 2012; Schuster et al., 2010, 2011). These various archives and long-term measurements were influenced by factors such as diverse sources or post-depositional effects that may explain some of the differences observed between the results.

\section{Conclusions}

The results of this first study of PFASs and PBDEs in a firn core from the European Alps demonstrate the occurrence, accumulation and recent changes of these persistent organic pollutants in Alpine regions. We did not observe trends in PBDEs, but PFAS changed from PFOA to a PFBA dominated composition. The persistence of PFASs and PBDEs has implications for water resources; as they are likely to be remobilized in glacial meltwater and eventually reach drinking water supplies. Future analyses of natural archives and long-term monitoring programs will demonstrate if governmental regulations and voluntary activities by industry will lead to a reduction of persistent organic pollutants in the alpine environment. 


\section{Acknowledgments}

We thank the Paul Scherrer Institute for funding the core drilling, analysis of major ions and stable isotopes, and dating the firn core.

\section{Appendix A. Supporting information}

Supplementary material associated with this article can be found, in the online version, at http://dx.doi.org/10.1016/j.envpol. 2013.03.043.

\section{References}

3M, 2010. 3M's Phase Out and New Technologies. http://solutions.3m.com/wps/ portal/3M/en_US/PFOS/PFOA/Information/phase-out-technologies/.

Ahrens, L., Yamashita, N., Yeung, L.W.Y., Taniyasu, S., Horii, Y., Lam, P.K.S., Ebinghaus, R., 2009. Partitioning behavior of per- and polyfluoroalkyl compounds between pore water and sediment in two sediment cores from Tokyo Bay, Japan. Environmental Science \& Technology 43, 6969-6975.

Ahrens, L, Marusczak, N., Rubarth, J., Dommergue, A., Nedjai, R., Ferrari, C., Ebinghaus, R., 2010. Distribution of perfluoroalkyl compounds and mercury in fish liver from high-mountain lakes in France originating from atmospheric deposition. Environmental Chemistry 7, 422.

Ahrens, L., 2011. Polyfluoroalkyl compounds in the aquatic environment: a review of their occurrence and fate. Journal of Environmental Monitoring 13, 20-31.

Ahrens, L., Herzke, D., Huber, S., Bustnes, J.O., Bangjord, G., Ebinghaus, R., 2011. Temporal trends and pattern of polyfluoroalkyl compounds in Tawny Owl (Strix aluco) eggs from Norway, 1986-2009. Environmental Science \& Technology 45, 8090-8097.

Ahrens, L., Harner, T., Shoeib, M., Lane, D.A., Murphy, J.G., 2012. Improved characterization of gas-particle partitioning for per- and polyfluoroalkyl substances in the atmosphere using annular diffusion denuder samplers. Environmental Science \& Technology 46, 7199-7206.

Arellano, L., Fernández, P., Tatosova, J., Stuchlik, E., Grimalt, J.O., 2011. Long-range transported atmospheric pollutants in snowpacks accumulated at different altitudes in the Tatra Mountains (Slovakia). Environmental Science \& Technology 45, 9268-9275.

Armitage, J.M., MacLeod, M., Cousins, I.T., 2009. Comparative assessment of the global fate and transport pathways of long-chain perfluorocarboxylic acids (PFCAs) and perfluorocarboxylates (PFCs) emitted from direct sources. Environmental Science \& Technology 43, 5830-5836.

Arp, H.P.H., Goss, K.-U., 2009. Gas/particle partitioning behavior of perfluorocarboxylic acids with terrestrial aerosols. Environmental Science \& Technology 43, 8542-8547.

Barton, C., Butler, L., Zarzecki, C., 2006. Characterizing perfluorooctanoate in ambient air near the fence line of a manufacturing facility: comparing modeled and monitored values. Journal of the Air \& Waste Management Association 56, $37-41$.

Belis, C.A., Offenthaler, I., Uhl, M., Nurmi-Legat, J., Bassan, R., Jakobi, G., Kirchner, M., Knoth, W., Kräuchi, N., Levy, W., Magnani, T., Moche, W., Schramm, K.-W., Simoncic, P., Weiss, P., 2009. A comparison of Alpine emissions to forest soil and spruce needle loads for persistent organic pollutants (POPs). Environmental Pollution 157, 3185-3191.

Birnbaum, L.S., Staskal, D.F., 2003. Brominated flame retardants: cause for concern? Environmental Health Perspectives 112, 9-17.

Bogdal, C., Kohler, M., Schmid, P., Scheringer, M., Hungerbühler, K., 2007. Partitioning of polybrominated diphenyl ethers between air, water, sediment and fish in Lake Thun (Switzerland). Organohalogen Compounds 69, 441-444.

Bogdal, C., Schmid, P., Kohler, M., Müller, C.E., Iozza, S., Bucheli, T.D., Scheringer, M., Hungerbühler, K., 2008. Sediment record and atmospheric deposition of brominated flame retardants and organochlorine compounds in Lake Thun, Switzerland: lessons from the past and evaluation of the present. Environmental Science \& Technology 42, 6817-6822.

Bogdal, C., Schmid, P., Zennegg, M., Anselmetti, F.S., Scheringer, M., Hungerbühler, K., 2009. Blast from the past: melting glaciers as a relevant source for persistent organic pollutants. Environmental Science \& Technology 43, 8173-8177.

Bossi, R., Skov, H., Vorkamp, K., Christensen, J., Rastogi, S.C., Egeløv, A., Petersen, D., 2008. Atmospheric concentrations of organochlorine pesticides, polybrominated diphenyl ethers and polychloronaphthalenes in Nuuk, South-West Greenland. Atmospheric Environment 42, 7293-7303.

Breivik, K., Wania, F., Muir, D.C.G., Alaee, M., Backus, S., Pacepavicius, G., 2006 Empirical and modeling evidence of the long-range atmospheric transport of decabromodiphenyl ether. Environmental Science \& Technology 40, 4612-4618.

Butt, C.M., Berger, U., Bossi, R., Tomy, G.T., 2010. Levels and trends of poly- and perfluorinated compounds in the arctic environment. The Science of the Total Environment 408, 2936-2965.

Cuffey, K.M., Paterson, W.S.B., 2010. The Physics of Glaciers, fourth ed. Academic Press.
Daly, G.L., Wania, F., 2004. Simulating the influence of snow on the fate of organic compounds. Environmental Science \& Technology 38, 4176-4186.

De Wit, C.A., 2002. An overview of brominated flame retardants in the environment. Chemosphere 46, 583-624.

Dreyer, A., Weinberg, I., Temme, C., Ebinghaus, R., 2009a. Polyfluorinated compounds in the atmosphere of the Atlantic and Southern Oceans: evidence for a global distribution. Environmental Science \& Technology 43, 6507-6514.

Dreyer, A., Matthias, V., Temme, C., Ebinghaus, R., 2009b. Annual time series of air concentrations of polyfluorinated compounds. Environmental Science \& Technology 43, 4029-4036.

Dreyer, A., Matthias, V., Weinberg, I., Ebinghaus, R., 2010. Wet deposition of polyand perfluorinated compounds in Northern Germany. Environmental Pollution $158,1221-1227$.

Dreyer, A., Thuens, S., Kirchgeorg, T., Radke, M., 2012. Ombrotrophic peat bogs are not suited as natural archives to investigate the historical atmospheric deposition of perfluoroalkyl substances. Environmental Science \& Technology 46, $7512-7519$.

Dreyer, A., Weinberg, I., Kirchgeorg, T., 2011. Particle size distribution of airborne perfluorinated compounds. Organohalogen Compouds 73, 255-258.

Eichler, A., Schwikowski, M., Furger, M., Schotterer, U., Gäggeler, H.W., 2004. Sources and distribution of trace species in Alpine precipitation inferred from two 60year ice core paleorecords. Atmospheric Chemistry and Physics Discussions 4, 71-108.

Ellision, S.L.R., Williams, A. (Eds.), 2000. EURACHEM/CITAC Guide CG 4-Quantifying Uncertainty in Analytical Measurement, second ed.

European Union, 2003. Directive 2003/11/EC of the European Parliament and of the Council of 6 February 2003 amending for the 24th time Council Directive 76/ $769 /$ EEC relating to restrictions on the marketing and use of certain dangerous substances and preparations.

European Union, 2006. Directive 2006/122/ECOF on the approximation of the laws, regulations and administrative provisions of the Member States relating to restrictions on the marketing and use of certain dangerous substances and preparations (perfluorooctane sulfonates).

Fiedler, S., Pfister, G., Schramm, K.-W., 2010. Poly- and perfluorinated compounds in household consumer products. Toxicological \& Environmental Chemistry 92, $1801-1811$.

Freberg, B.I., Haug, L.S., Olsen, R., Daae, H.L., Hersson, M., Thomsen, C., Thorud, S., Becher, G., Molander, P., Ellingsen, D.G., 2010. Occupational exposure to airborne perfluorinated compounds during professional ski waxing. Environmental Science \& Technology 44, 7723-7728.

Gabrieli, J., Vallelonga, P., Cozzi, G., Gabrielli, P., Gambaro, A., Sigl, M., Decet, F., Schwikowski, M., Gäggeler, H., Boutron, C., Cescon, P., Barbante, C., 2010. Post 17th-century changes of European PAH emissions recorded in high-altitude Alpine snow and ice. Environmental Science \& Technology 44, 3260-3266.

Gouin, T. Thomas, G.O. Chaemfa, C. Harner, T, Mackay, D., Jones, K.C., 2006. Concentrations of decabromodiphenyl ether in air from Southern Ontario: implications for particle-bound transport. Chemosphere 64, 256-261.

Harner, T., Shoeib, M., 2002. Measurements of octanol-air partition coefficients (KOA) for polybrominated diphenyl ethers (PBDEs): predicting partitioning in the environment. Journal of Chemical \& Engineering Data 47, 228-232.

Hassanin, A., Johnston, A.E., Thomas, G.O., Jones, K.C., 2005. Time trends of atmospheric PBDEs inferred from archived U.K. herbage. Environmental Science \& Technology 39, 2436-2441.

Hermanson, M.H., Isaksson, E., Forsström, S., Teixeira, C., Muir, D.C.G., Pohjola, V.A., Van de Wal, R.S.V., 2010. Deposition history of brominated flame retardant compounds in an ice core from Holtedahlfonna, Svalbard, Norway. Environmental Science \& Technology 44, 7405-7410.

Hites, R.A., 2004. Polybrominated diphenyl ethers in the environment and in people: a meta-analysis of concentrations. Environmental Science \& Technology 38, 945-956.

Jenk, T.M., Szidat, S., Bolius, D., Sigl, M., Gäggeler, H.W., Wacker, L., Ruff, M., Barbante, C., Boutron, C.F., Schwikowski, M., 2009. A novel radiocarbon dating technique applied to an ice core from the Alps indicating late Pleistocene ages. Journal of Geophysical Research 114

Kaiser, M.A., Larsen, B.S., Kao, C.C., Buck, R.C., 2005. Vapor pressures of perfluorooctanoic, -nonanoic, -decanoic, -undecanoic, and -dodecanoic acids. Journal of Chemical \& Engineering Data 50, 1841-1843.

Kirchgeorg, T., Weinberg, I., Dreyer, A., Ebinghaus, R., 2010. Perfluorinated compounds in marine surface waters: data from the Baltic Sea and methodological challenges for future studies. Environmental Chemistry 7, 429.

Kohler, M., Zennegg, M., Bogdal, C., Gerecke, A.C., Schmid, P., Heeb, N.V., Sturm, M., Vonmont, H., Kohler, H.-P.E., Giger, W., 2008. Temporal trends, congener patterns, and sources of octa-, nona-, and decabromodiphenyl ethers (PBDE) and hexabromocyclododecanes (HBCD) in Swiss lake sediments. Environmental Science \& Technology 42, 6378-6384.

Kratzer, J., Ahrens, L., Roos, A., Bäcklin, B.-M., Ebinghaus, R., 2011. Temporal trends of polyfluoroalkyl compounds (PFCs) in liver tissue of grey seals (Halichoerus grypus) from the Baltic Sea, 1974-2008. Chemosphere 84, 1592-1600.

Kwok, K.Y., Taniyasu, S., Yeung, L.W.Y., Murphy, M.B., Lam, P.K.S., Horii, Y., Kannan, K., Petrick, G., Sinha, R.K., Yamashita, N., 2010. Flux of perfluorinated chemicals through wet deposition in Japan, the United States, and several other countries. Environmental Science \& Technology 44, 7043-7049.

Lau, C., Anitole, K., Hodes, C., Lai, D., Pfahles-Hutchens, A., Seed, J., 2007. Perfluoroalkyl acids: a review of monitoring and toxicological findings. Toxicological Sciences 99, 366-394. 
Loewen, M., Wania, F., Wang, F., Tomy, G., 2008. Altitudinal transect of atmospheric and aqueous fluorinated organic compounds in Western Canada. Environmental Science \& Technology 42, 2374-2379.

Lugauer, M., Baltensperger, U., Furger, M., Gaggeler, H.W., Jost, D.T. Schwikowski, M., Wanner, H., 1998. Aerosol transport to the high Alpine sites Jungfraujoch (3454 m asl) and Colle Gnifetti (4452 m asl). Tellus B 50, 76-92.

Mariani, G., Canuti, E., Castro-Jiménez, J., Christoph, E.H., Eisenreich, S.J., Hanke, G., Skejo, H., Umlauf, G., 2008. Atmospheric input of POPs into Lake Maggiore (Northern Italy): PBDE concentrations and profile in air, precipitation, settling material and sediments. Chemosphere 73, 114-121.

Meyer, T., Muir, D.C.G., Teixeira, C., Wang, X., Young, T., Wania, F., 2012. Deposition of brominated flame retardants to the Devon Ice Cap, Nunavut, Canada. Environmental Science \& Technology 46, 826-833.

Möller, A., Xie, Z., Sturm, R., Ebinghaus, R., 2011. Polybrominated diphenyl ethers (PBDEs) and alternative brominated flame retardants in air and seawater of the European Arctic. Environmental Pollution 159, 1577-1583.

Offenthaler, I., Bassan, R., Belis, C., Garo-Stach, I., Ganz, S., Iozza, S., Jacobi, G., Kaiser A., Kirchner, M., Knoth, W., Kräuchi, N., Levy, W., Moche, W., Nurmi-Legat, J. Raccaneli, S., Schramm, K.-W., Schröder, P., Sedivy, I., Simoncic, P., Staudinger M., Thanner, G., Uhl, M., Vilhar, U., Weiss, P., 2009. MONARPOP - Technical Report.

Prevedouros, K., Cousins, I.T., Buck, R.C., Korzeniowski, S.H., 2006. Sources, fate and transport of perfluorocarboxylates. Environmental Science \& Technology 40, $32-44$.

Renner, R., 2006. The long and the short of perfluorinated replacements. Environmental Science \& Technology 40, 12-13.

Reth, M., Berger, U., Broman, D., Cousins, I.T., Nilsson, E.D., McLachlan, M.S., 2011 Water-to-air transfer of perfluorinated carboxylates and sulfonates in a sea spray simulator. Environmental Chemistry 8, 381-388.

Schenker, U., Scheringer, M., MacLeod, M., Martin, J.W., Cousins, I.T., Hungerbühler, K., 2008a. Contribution of volatile precursor substances to the flux of perfluorooctanoate to the Arctic. Environmental Science \& Technology $42,3710-3716$

Schenker, U., Soltermann, F., Scheringer, M., Hungerbühler, K., 2008b. Modeling the environmental fate of polybrominated diphenyl ethers (PBDEs): the importance of photolysis for the formation of lighter PBDEs. Environmental Science \& Technology 42, 9244-9249.

Schuster, J.K., Gioia, R., Breivik, K., Steinnes, E., Scheringer, M., Jones, K.C., 2010. Trends in European background air reflect reductions in primary emissions of PCBs and PBDEs. Environmental Science \& Technology 44, 6760-6766.

Schuster, J.K., Gioia, R., Moeckel, C., Agarwal, T., Bucheli, T.D., Breivik, K., Steinnes, E. Jones, K.C., 2011. Has the burden and distribution of PCBs and PBDEs changed in European background soils between 1998 and 2008? Implications for sources and processes. Environmental Science \& Technology 45, 7291-7297.

Schwikowski, M., Barbante, C., Doering, T., Gaeggeler, H.W., Boutron, C. Schotterer, U., Tobler, L., Van de Velde, K., Ferrari, C., Cozzi, G., Rosman, K. Cescon, P., 2004. Post-17th-century changes of european lead emissions recorded in high-altitude alpine snow and ice. Environmental Science \& Technology 38, 957-964.

Scott, B.F., Spencer, C., Mabury, S.A., Muir, D.C.G., 2006. Poly and perfluorinated carboxylates in North American precipitation. Environmental Science \& Technology 40, 7167-7174

Shotyk, W., MacKenzie, A., Norton, S., 2004. Archives of environmental contamination. Journal of Environmental Monitoring 6, 417.

Sigl, M., 2009. Ice core based reconstruction of past climate conditions from Colle Gnifetti, Swiss Alps. Ph.D. dissertation, University of Bern.
Steele, W.V., Chirico, R.D., Knipmeyer, S.E., Nguyen, A., 2002. Vapor pressure, heat capacity, and density along the saturation line: measurements for benzenamine, butylbenzene, sec-butylbenzene, tert-butylbenzene, 2,2-dimethylbutanoic acid, tridecafluoroheptanoic acid, 2-butyl-2-ethyl-1,3-propanediol, 2,2,4-trimethyl. Journal of Chemical \& Engineering Data 47, 648-666.

Stockholm Convention, 2009a. SC-4/17: listing of perfluorooctane sulfonic acid, its salts and perfluorooctane sulfonyl fluoride.

Stockholm Convention, 2009b. SC-4/18: listing of tetrabromodiphenyl ether and pentabromodiphenyl ether.

Sturm, R., Ahrens, L., 2010. Trends of polyfluoroalkyl compounds in marine biota and in humans. Environmental Chemistry 7, 457-484.

Suter, S., Hoelzle, M., 2002. Cold firn in the Mont Blanc and Monte Rosa areas, European Alps: spatial distribution and statistical models. Annals of Glaciology 35, 9-18.

Ter Schure, A.F.H., Larsson, P., 2002. Polybrominated diphenyl ethers in precipitation in Southern Sweden (Skane, Lund). Atmospheric Environment 36, 40154022.

Ter Schure, A.F.H., Agrell, C., Bokenstrand, A., Sveder, J., Larsson, P., Zegers, B.N 2004. Polybrominated diphenyl ethers at a solid waste incineration plant II: atmospheric deposition. Atmospheric Environment 38, 5149-5155.

Vierke, L., Ahrens, U., Shoeib, M., Reiner, E.J., Guo, R., Palm, W.-U., Ebinghaus, R., Harner, T., Lu, D.-, 2011. Air concentrations and particle-gas partitioning of polyfluoroalkyl compounds at a wastewater treatment plant. Environmental Chemistry 8, 363-371.

Villa, S., Negrelli, C., Maggi, V., Finizio, A., Vighi, M., 2006. Analysis of a firn core for assessing POP seasonal accumulation on an Alpine glacier. Ecotoxicology and Environmental Safety 63, 17-24.

Wang, P., Zhang, Q., Wang, Y., Wang, T., Li, X., Li, Y., Ding, L., Jiang, G., 2009. Altitude dependence of polychlorinated biphenyls (PCBs) and polybrominated diphenyl ethers (PBDEs) in surface soil from Tibetan Plateau, China. Chemosphere 76 1498-1504.

Wania, F., 1997. Modelling the fate of non-polar organic chemicals in an ageing snow pack. Chemosphere 35, 2345-2363.

Wania, F., Westgate, J.N., 2008. On the mechanism of mountain cold-trapping of organic chemicals. Environmental Science \& Technology 42, 9092-9098.

Wania, F., Dugani, C.B., 2003. Assessing the long-range transport potential of diphenyl ethers: a comparison of four multimedia models. Environmental Toxicology and Chemistry 22, 1252-1261.

Watanabe, I., 2003. Environmental release and behavior of brominated flame retardants. Environment International 29, 665-682.

Webster, E., Ellis, D.A.A., 2010. Potential role of sea spray generation in the atmospheric transport of perfluorocarboxylic acids. Environmental Toxicology and Chemistry/SETAC 29, 1703-1708.

Weinberg, I., Dreyer, A., Ebinghaus, R., 2011a. Landfills as sources of polyfluorinated compounds, polybrominated diphenyl ethers and musk fragrances to ambient air. Atmospheric Environment 45, 935-941.

Weinberg, I., Dreyer, A., Ebinghaus, R., 2011b. Waste water treatment plants as sources of polyfluorinated compounds, polybrominated diphenyl ethers and musk fragrances to ambient air. Environmental Pollution 159, 125-132. (Barking, Essex: 1987)

Young, C.J., Furdui, V.I., Franklin, J., Koerner, R.M., Muir, D.C.G., Mabury, S.A., 2007. Perfluorinated acids in Arctic snow: new evidence for atmospheric formation. Environmental Science \& Technology 41, 3455-3461.

Young, C.J., Mabury, S.A., 2010. Atmospheric perfluorinated acid precursors: chemistry, occurrence, and impacts. In: De Voogt. P. (Ed), 2010. Reviews of Environmental Contamination and Toxicology, vol. 208. Springer, New York, NY. 